\title{
Bir Eğitim ve Araştırma Hastanesine Başvuran Adölesan Gebelerin Tıbbi, Sosyal ve Hukuki Açıdan İncelenmesi
}

\section{Medical, Social and Legal Evaluation of Adolescent Pregnancies, who Applied to a Training and Research Hospital}

\author{
(D)Orhan Meral', (DAslı Şener², (DTeoman Şen ${ }^{3}$ \\ İZzmir Bakırçay Üniversitesi Çiğli Eğitim ve Araştırma Hastanesi, Adli Tıp, İzmir, Türkiye \\ 2izzmir Bakırçay Üniversitesi Çiğli Eğitim ve Araştırma Hastanesi, Acil Tıp, İzmir, Türkiye \\ ${ }^{3}$ İzmir Bakırçay Üniversitesi Çiğli Eğitim ve Araştırma Hastanesi, Çocuk Cerrahisi, İzmir, Türkiye \\ Copyright@Author(s) - Available online at www.dergipark.org.tr/tr/pub/medr \\ Content of this journal is licensed under a Creative Commons Attribution-NonCommercial 4.0 International License.
}

\begin{abstract}
Öz
Amaç: Adölesan gebelikler ülkemizde ve dünyada önemli bir halk sağlığı sorunu olarak karşımıza çıkmaktadır. Bu gebeliklerin önlenebilmesi için her ülke kendi iç politikalarını düzenlemiştir. Ülkemizde de evlilik ve cinsel ilişki yaş sınırları kanunla belirlenmiştir. Bu çalışmada Ocak 2018 - Ağustos 2020 tarihleri arasında Çiğli Eğitim ve Araştırma Hastanesi'ne başvuran, yapılan muayene ve tetkikler sonucunda gebe olduğu belirlenen 18 yaş altı olguların incelenerek, elde edilen verilerin literatürle tartışılması amaçlanmıştır. Materyal ve Metot: Çalışma kapsamına alınan 18 yaş altı 260 gebe olguya ait tıbbi kayıtlar Hastane Bilgi Yönetim Sistemi üzerinden incelenmiștir. Veriler SPSS programı (versiyon 22.0) ile analiz edilmiştir. Analiz için Fisher Exact ve Pearson ki-kare testleri kullanılmıştır.

Bulgular. Adölesan gebelerin ilk hastane başvurusuna yaşları 13-17 arasında değişmekte olup ortalaması 16,4 $\pm 0,7$ olarak hesaplanmıştır. Medeni durum bilgisine ulaşılan 39 olgudan 31 'inin $(\% 79,4)$ resmi nikâhlı, 4 olgunun $(\% 10,3)$ ise bekâr olduğu görülmüştür. Adölesanların gebe olduklarının belirlendiği ilk başvurularında gebelik haftaları 3 ila 41 hafta arasında değişmekte olup, 142 olgunun $(\% 54,6)$ gebeliğinin üçüncü trimesterde olduğu tespit edilmiştir.

Sonuç: Eğitim kurumlarında cinsel sağlık derslerinin yaygınlaştırılması, sağlık kurumlarında adölesan gebeliklerin zararları konusunda hizmet veren polikliniklerin oluşturulması, adölesan gebeliğin kişi ve toplum sağlığı üzerine olumsuz etkilerinin ve ayrıca bir suç teşkil edebileceği gibi hukuki sonuçlarının topluma yeterince duyurulmasının faydalı olacağını düşünmekteyiz.
\end{abstract}

Anahtar Kelimeler. Adölesan; Adölesan gebelik; Tıbbi, sosyal ve hukuki inceleme

\begin{abstract}
Aim: Adolescent pregnancies emerge as an important public health problem in our country and in the world. Each country has arranged its own internal policies in order to prevent these pregnancies. In our country, age limits for marriage and sexual intercourse are regulated by law. In this study, it was aimed to evaluate the cases less than age of 18 who applied to Çiğli Training and Research Hospital between January 2018 and August 2020 and were determined to be pregnant as a result of the examinations and tests, and to discuss the obtained data with the literature.

Material and Method: Medical records of 260 pregnant cases less than 18 years of age included in the study were analyzed through the Hospital Information Management System. The data were analyzed with the SPSS program (version 22.0). Fisher Exact and Pearson chi-square tests were used for analysis.

Results: The ages of adolescent pregnant women at their first hospital admission ranged between 13-17 and their average was calculated as $16.4 \pm 0.7$. It was observed that 31 (79.4\%) of the 39 cases whose marital status information was obtained were officially married, and 4 cases (10.3\%) were single. Gestational weeks ranged from 3 to 41 weeks when adolescents were determined to be pregnant, and it was found that the pregnancy of 142 cases $(54.6 \%)$ was in the third trimester.

Conclusion: We think that it will be beneficial to disseminate sexual health courses in educational institutions, establish polyclinics that provide service on the harms of adolescent pregnancies in health institutions, and to adequately announce the negative effects of adolescent pregnancy on individual and public health, as well as its legal consequences.
\end{abstract}

Keywords: Adolescent; Adolescent pregnancies; Medical, social and legal evaluation 


\section{GíRiş}

Fransızca kökenli olup "buluğ çağına erişmiş", "büyümekte" anlamlarına gelen adölesan sözcüğü, en geniş anlamıyla "bireyin biyolojik, psikolojik, bilişsel, sosyal ve cinsel değişimlerle birlikte çocukluktan erginliğe geçiş dönemi" olarak tanımlanmakta, Dünya Sağlık Örgütü (DSÖ) bu dönemi 10-19 yaş aralığı olarak ifade etmektedir (1-6).

Adölesan dönem gebeliklerinin tüm dünya ülkelerinde ciddi bir sağlık problemi olarak karşımıza çıktığı görülmektedir $(1,7)$. Gelişmiş ülkelerdeki adölesan gebeliklerin \%80'inin evlilik dışı, istenmeyen veya planlanmamış gebelikler olduğu belirtilmektedir $(8,9)$. Büyük çoğunluğu az gelişmiş ya da gelişmekte olan ülkelerde olmak üzere, dünya genelinde yılda ortalama 14-15 milyon civarında adölesan gebenin doğum yaptığı bildirilmekte olup, bu doğumlar tüm doğumların \%10'una karşlıık gelmektedir (10). Türkiye Nüfus ve Sağlık Araştırması (TNSA) 2018 verilerine göre; ülke nüfusunun \%16'sını adölesan yaş grubunun oluşturduğu ve adölesan yaş grubunda doğum yapmış olanların tüm adölesanlara oranının \%4 olduğu rapor edilmiştir (11). Türkiye İstatistik Kurumu (TÜiK) verilerine göre; ülkemizde 2015 yılında \%2,6 olan 15-19 yaş grubu doğurganlık hızının, 2016 yılında \%2,4, 2017 yılında \%2,2, 2018 yılında \%1,9, 2019 yılında ise \%1,7'ye gerilediği belirtilmiştir. Yine aynı kurum verilerine göre; 2001-2018 yılları arasında 15 yaş altı 20 bin 589 adölesanın doğum yapmış olduğu bildirilmiş, 2019 yılı verilerine ise yer verilmemiştir (12).

Adölesan dönem gebeliklerinde birçok faktör rol oynamaktadır. Bunlar arasında menarş yaşının azalmasıyla birlikte erken yaşta cinsel ilişkiye girilmesi, sosyo-ekonomik düzey düşüklüğü ve inanç değerlerinin etkisi ilk sıralarda gelmektedir. Gelişmekte veya az gelişmiş olan ülkelerde düşük ve orta düzeyde gelire sahip ailelerin kızlarının \%30'a yakınının 18 yaşından önce, \%14'ü'nün ise 15 yaşından önce evlendiği ve adölesan dönem gebeliği ile karşı karşıya kaldığı bildirilmiştir $(13,14)$.

Üçüncü basamak bir eğitim ve araştırma hastanesi olan kurumumuzun yoğun göç alan İzmir ilinde bulunması, ayrıca sosyal, kültürel ve ekonomik durum ile eğitim düzeyi açısından nispeten düşük-orta seviyede bir nüfusa hizmet vermesi nedeniyle adölesan gebeliklerle oldukça sık karşılaşılmaktadır. Bu araştırmanın amacı; Ocak 2018 - Ağustos 2020 tarihleri arasında Çiğli Eğitim ve Araştırma Hastanesi'ne başvuran, yapılan muayene ve tetkikler sonucunda gebe olduğu belirlenen 18 yaş altı olguların sosyo-demografik özelliklerini, hastaneye başvuru nedenlerini, başvuru sırasında saptanan gebelik sürelerini, sağlık durumlarını ve gebelik sonuçlarını belirlemek, elde edilen verileri literatürle tartışarak hastanemizin verilerini değerlendirmek, ülkemizin her bölgesinden ve hatta yurtdışından göç alan İzmir ilinin adölesan gebelikler ve sonuçları ile ilgili istatistiği konusunda fikir elde edebilmek, bu gebeliklerin tıbbi ve sosyal zararları ile hukuki sakıncalarını gözden geçirmek, adölesan evlilik ve gebeliklerin idari ve cezai açıdan yeniden değerlendirilmesi konusunda önerilerde bulunmaktır.

\section{MATERYAL VE METOT}

\section{Verilerin elde edilmesi}

Araştırmamız kesitsel-tanımlayıcı nitelikte olup geriye dönük yapılmıştır. Ocak 2018 - Ağustos 2020 tarihleri arasında Bakırçay Üniversitesi Çiğli Eğitim ve Araştırma Hastanesi'ne başvuran ve çalışma kapsamına alınan 18 yaş altı 260 gebe olguya ait tıbbi kayıtlar Hastane Bilgi Yönetim Sistemi üzerinden incelenmiştir.

Olguların resmi kayıtlara göre doğum tarihi, doğum yeri ve uyruğu, medeni durumu, evli ise resmi nikâhlı olup olmadığı, eğitim durumu, hastaneye başvuru tarihi, başvuru sırasında saptanan gebelik haftası, kaçıncı gebelik olduğu, gebeliğin sonucu (canlı ve sağlıklı doğum / ölü doğum / abortus) ve hastanemizde hangi birimde adli bildirim yapıldığına ait bilgiler hazırlanan Olgu Rapor Formlarına kaydedilmiş, elde edilen veriler bilgisayar ortamına aktarılmıştır.

\section{İstatistiksel analiz}

Veriler SPSS programı (versiyon 22.0) ile analiz edilmiştir. Demografik veriler ortalama değer \pm standart sapma ve/ veya yüzde olarak ifade edilmiştir. Analizlerde frekans, yüzde ve sayımla belirlenen verilerin analizinde Fisher Exact ve Pearson ki-kare testleri kullanılmıştır. Karşılaştırma değerleri \%95 güven aralığında hesaplanmış; $p<0,05$ olduğunda istatistiksel olarak anlamlı kabul edilmiştir.

\section{BULGULAR}

Çalışmaya alınan 260 adölesan olgunun gebe olduklarının saptandığındaki yaşları 13-17 arasında değişmekte olup ortalaması $16,4 \pm 0,7$ olarak hesaplandı. 8 olgunun $(\% 3,1)$ gebe kaldığında 15 yaşın altında, 252 olgunun ise $(\% 96,9)$ 15,16 veya 17 yaşlarında olduğu belirlendi.

Medeni durum bilgisine ulaşılan 39 olgudan 31 'inin $(\% 79,4)$ resmi nikâhlı, 4 olgunun $(\% 10,3)$ ise bekâr olduğu görüldü.

Adölesanların 192'sinin (\%73,8) Türkiye, 61'inin (\%23,5) Suriye vatandaşı olduğu görüldü. Türkiye vatandaşı olan adölesanların 97'sinin (\%50,5) Ege, 50'sinin (\%26) Doğu Anadolu, 24'ünün $(\% 12,5)$ ise Güney Doğu Anadolu bölgesinde doğmuş olduğu belirlendi. Olgulara ait demografik veriler tabloda gösterildi (Tablo 1).

Adölesanların tıbbi geçmişlerine bakıldığında; 215 olgunun $(\% 82,7)$ ilk, 44 olgunun $(\% 16,9)$ ikinci, 1 olgunun $(\% 0,4)$ ise üçüncü gebeliği olduğu tespit edildi. İkinci gebeliği olan olgulardan 36 'sının $(\% 81,8)$ ilk gebeliğinin sonucunda canlı ve sağlıklı çocuk doğurduğu, ancak 8'inin $(\% 18,2)$ ise düşük yaptığı bilgisine ulaşıldı.

Adölesan gebeliklerin daha sık olarak $2019 \quad(n=118$, $\% 45,4)$ ve $2018(n=95, \% 36,5)$ yıllarında, ayrıca Temmuz $(n=36, \% 13,8)$ ve Mayıs aylarında $(n=30, \% 11,5)$ hastaneye başvurduğu saptandı.

Adölesanların gebe olduklarının belirlendiği ilk başvurularında gebelik haftaları 3 ila 41 hafta arasında değişmekte olup, 142 olgunun $(\% 54,6)$ gebeliğinin üçüncü trimesterde olduğu tespit edildi. 
Tablo 1. Adölesan gebelere ait demografík veriler

\begin{tabular}{lc} 
Yaş aralığı & $13-17$ \\
Ortalama yaş & $16,40,7$ \\
Yaş grupları & $\mathrm{n}(\%)$ \\
15 yaş altı & $8(3,1)$ \\
16-17-18 yaş & $252(96,9)$ \\
Medeni durum & $\mathrm{n} *(\%)$ \\
Resmi nikâhlı & $31(79,4)$ \\
Dini nikâhlı & $4(10,3)$ \\
Bekâr & $4(10,3)$ \\
Uyruk & $\mathrm{n}(\%)$ \\
Türkiye & $192(73,8)$ \\
Suriye & $61(23,5)$ \\
Irak & $4(1,5)$ \\
Ürdün & $2(0,8)$ \\
Avustralya & $1(0,4)$ \\
Doğum yeri bölgesi & $\mathrm{n} *(\%)$ \\
Ege Bölgesi & $97(50,5)$ \\
Doğu Anadolu Bölgesi & $50(26,1)$ \\
Güneydoğu Anadolu Bölgesi & $24(12,5)$ \\
Marmara Bölgesi & $7(3,6)$ \\
Karadeniz Bölgesi & $6(3,1)$ \\
Akdeniz Bölgesi & $4(2,1)$ \\
İç Anadolu Bölgesi & $4(2,1)$ \\
& \\
\hline
\end{tabular}

* Medeni durum bilgisine ulaşılan toplam adölesan sayısı 39'dur. ** Türkiye vatandaşı olan toplam adölesan sayısı 192 'dir.

Adölesanların 159'unun gebeliklerinin nasıl sonuçlandığı bilgisine ulaşılmış olup, bu olguların \%85,5'inin $(n=136)$ hastanemizde canlı ve sağlıklı doğum yaptığı, \%8,2'sinin $(n=13)$ sevk edildiği, \%6,3'ünün $(n=10)$ gebeliğinin abortusla sonuçlandığı saptandı. Olguların tıbbi durumları ve hastane başvurularına ilişkin veriler tabloda gösterildi (Tablo 2).

138 adölesanın $(\% 53,1)$ Kadın Hastalıkları ve Doğum polikliniğinde, 122 'sinin $(\% 46,9)$ ise Acil Serviste gebe olduğu saptanmış olup aynı birim hekimlerince adli birimlere bildirim yapıldığı tespit edildi.

Çalışmadan elde edilen veriler Fisher Exact ve Pearson kikare testleri kullanılarak karşılaştııılmıştır. Adölesanların uyruğu ile gebelik trimesteri karşılaştırıldığında; yabancı uyruklu 68 olgunun \%76,5'inin ( $n=52) 3$. trimesterde olduğu $(p=0,000)$, uyruk ve gebe kalma yaşları karşılaştırıldığında; Türkiye uyruklu olguların $\% 0,5^{\prime}$ inin $(n=1)$, yabancı uyruklu olguların ise \%10,3'ünün $(n=7) 15$ yaşın altında olduğu $(p=0,000)$, ayrıca 15 yaş altı 8 olgunun 7 'sinin $(\% 87,5)$ yabancı uyruklu olduğu $(p=0,000)$, yaş grupları ve saptanan gebelik trimesterleri karşılaştırıldığında; 15 yaşın altındaki 8 adölesanın 7 'sinin $(\% 87,5) 3$. trimesterde olduğu $(p<0,05)$ belirlendi.

\section{Tablo 2. Olguların tıbbi durumları ve hastane başvurularına ilişkin veriler}

Gebelik sayısı

Illk gebelik

İkinci gebelik

$44(16,9)$

Üçüncü gebelik

$1(0,4)$

Illk hastane başvurusu yilı

2018

$95(36,5)$

2019

$118(45,4)$

2020

$47(18,1)$

Illk hastane başvurusu ayı

$\mathrm{n}(\%)$

Ocak

Şubat

Mart

Nisan

Mayıs

Haziran

Temmuz

$36(13,8)$

Ağustos

Eylül

Ekim

Kasım

Aralık

Illk hastane başvurusu gebelik haftası

3-41 hafta arası

Illk hastane başvurusu gebelik trimesteri

n (\%)

ilk trimester

$74(28,5)$

İkinci trimester

$44(16,9)$

Üçüncui trimester

$142(54,6)$

Gebelik sonucu

$\mathrm{n} *(\%)$

Canlı ve sağlıklı doğum

$136(85,5)$

Sevk

Abortus

$10(6,3)$

* Gebelik sonucu bilgisine ulaşılan toplam adölesan sayısı 159'dur. 


\section{TARTIŞMA}

Adölesan gebelikler tüm dünyada bir sorun olarak karşımıza çıkmakta, bununla birlikte özellikle gelişmekte olan ve az gelişmiş ülkelerde adölesan gebeliklerin oranı her geçen gün artmaktadır. Bu çalışmaya alınan 260 adölesan olgunun gebe olduklarının saptandığındaki yaşları 13-17 arasında değişmekte olup ortalaması $16,4 \pm 0,7$ olarak hesaplanmıştır. Ülkemizde adölesan gebelere ilişkin yapılan çalışmalar incelendiğinde; yaş ortalaması Erzincan'da (3) 17,3 $\pm 0,9$, Hatay'da (15) $16,7 \pm 1,2$, Zonguldak'ta (16) $18,0 \pm 0,5$, Sakarya'da (17)

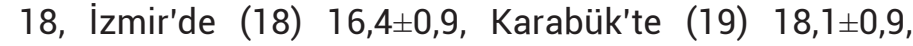
Van'da (20) 17,3 $\pm 1,3$, Kırşehir'de (21) 17,5 $\pm 0,7$, Ankara'da (6) $17,9 \pm 1,0$, Erzurum'da (22) $17,9 \pm 1,3$, Düzce'de (23) $17,5 \pm 0,7$, Adana'da (24) $16,6 \pm 0,8$ bulunmuştur. Sunulan çalışmada her yaştaki gebe adölesanlar ve tüm gebelik haftalarının çalışmaya dâhil edilmesi nedeniyle yaş ortalamasının diğer çalışmalara göre daha düşük olduğu düşünülmüştür.

Bu çalışmada olguların 252 olgunun (\%96,9) 15, 16 veya 17 yaşlarında olduğu, 8 olgunun $(\% 3,1)$ ise gebe kaldığında 15 yaşın altında olduğu belirlenmiştir. Melekoğlu ve ark. nın Adana'da yaptığı çalışmada (24) gebe adölesanların \%3,8'inin 10-13 yaş aralığında, İnalöz ve ark.nın Erzurum'da yaptığı çalışmada (22) gebe adölesanların \%30,4'ünün 17 yaş altında, Yılmaz ve ark.nın Ankara'da yaptığı çalışmada (6) ilk gebeliği olan adölesanların \%13,3'ünün 17 yaş altında olduğu rapor edilmiştir. Yapılan bir yurtdışı çalışmasında (25) adölesan dönemde gebe oldukları belirlenen olguların \%2,4'ünün 15 yaşın altında olduğu bildirilmiştir. Ülkemizde 4271 sayılı Türk Medeni Kanunu'na (TMK) göre, normal evlilik yaşı alt sınırı 17 yaş olarak belirlenmiştir. Mevcut yasaya göre, erkek veya kadın onyedi yaşını doldurmadıkça evlenemez. Ayrıca, olağanüstü durumlarda ve önemli bir sebeple, mümkün olduğu şartlarda ailenin de rızası ile mahkemece 16 yaşını doldurmuş olan erkek veya kadının evlenmesine izin verilebilmektedir (26). Olağanüstü sebeplere "evlenecek kızın gebe kalmış olması ile kimsesiz ve bakımsızlık içinde bulunması, erkeğin ise ölüm tehlikesiyle karşı karşıya bulunması" örnek gösterilmiştir (27). Türk Ceza Kanunu'na (TCK) göre "onbeş yaşını tamamlamamış veya tamamlamış olmakla birlikte fiilin hukuki anlam ve sonuçlarını algılama yeteneği gelişmemiş olanlara karşı gerçekleştirilen her türlü cinsel davranış çocuğun cinsel istismarı olarak tanımlanmış olup, çocuğu cinsel yönden istismar eden kişinin sekiz yıldan on beş yıla kadar hapis cezası ile cezalandırılacağı, ayrıca cebir, tehdit ve hile olmaksızın, onbeş yaşını bitirmiş olanla cinsel ilişkide bulunan kişinin de şikâyet üzerine, altı aydan iki yıla kadar hapis cezası ile cezalandırılacağı" belirtilmiştir (28).

Çalışmamızda sadece 39 olgunun (\%15) medeni durum bilgisine ulaşılmış olup bunlardan 31 'inin $(\% 79,4)$ resmi, 4 'ünün $(\% 10,3)$ dini nikâhlı olduğu, 4 olgunun $(\% 10,3)$ ise bekâr olduğu görülmüştür. Düzce (23) ilinde 83 adölesanın incelendiği çalışmada \%6,4'ünün, Sakarya (17) ilinde 77 adölesanın incelendiği çalışmada \%14'ünün,
Amasya (29) ilinde 272 adölesanın incelendiği çalışmada $\% 19,9^{\prime}$ unun, Erzincan (3) ilinde 222 adölesan gebenin incelendiği çalışmada olguların \%20,7'sinin, Adana (24) ilinde 182 adölesanın incelendiği çalışmada \%52,2'inin, İzmir (18) ilinde 282 adölesanın incelendiği bir çalışmada ise \%90,4'ünün resmi nikâhının olmadığı bildirilmiştir. Çin'de yapılan çalışmada (25) ise adölesan dönemde gebe oldukları belirlenen olguların \%5,1'inin bekâr olduğu bildirilmiştir. Çalışmamız da retrospektif özellikte olup olguların sadece \%15'inin medeni durum bilgisine ulaşılmıştır. Ülkemizde yapılan diğer çalışmalarda medeni durum bilgileri değişkenlik göstermektedir. Adölesan gebeliklerin medeni durum ile ilişkisinin olup olmadığı ve dolayısıyla gebeliklerin istemli / istemsiz olup olmadığı yönünde sağlıklı değerlendirme yapabilmek için hastane verilerinin düzenli tutulması büyük önem taşımaktadır.

Bu çalışmada olguların 192'sinin $(\% 73,8)$ Türkiye vatandaşı, 61'inin $(\% 23,5)$ Suriye uyruklu olduğu belirlenmişti. Ayrıca Türkiye vatandaşı olan adölesanların 97'sinin (\%50,5) Ege bölgesi, 50'sinin (\%26) Doğu Anadolu Bölgesi, 24'ünün $(\% 12,5)$ ise Güney Doğu Anadolu bölgesinde doğmuş olduğu belirleniştir. Sunulan çalışmada yaklaşık olarak 4 adölesandan birinin yabancı uyruklu olduğu, Türkiye vatandaşı olan olguların ise sadece yarısının Ege bölgesinde doğuş olduğu bilgisine ulaşılmıştır. Ülkemizde ve yurtdışında adölesan gebelerle ilgili birçok çalışma yapılmış olmakla birlikte olguların uyruk bilgisine yer verilen çalışmaya rastlanmamıştır. Suriye'de meydana gelen iç savaş sonucu sol yıllarda ülkemiz ve İzmir ili yoğun göç almıştır. Bunun yanı sıra, İzmir ilinin ülkenin her bölgesinden göç aldığı da göz önüne alındığında, çalışmamızda elde ettiğimiz uyruk ve doğum yeri oranları olağan karşılanmıştır.

Sunulan çalışmada adölesanların gebelik geçmişleri incelendiğinde; olguların \%82,7'sinin ilk, \%16,9'unun ikinci, \%0,4'ünün ise üçüncü gebeliğinin olduğu, ikinci gebeliği olan olguların \%81,8'i ilk gebeliğinin sonucunda canlı ve sağlıklı çocuk doğurmuşken, \%18,2'sinin düşük yaptığı bilgisine ulaşılmıştır. Ülkemizde yapılan diğer çalışmalar incelendiğinde; Hatay'da (15) adölesan olguların \%83'ünün, Ankara'da (6) ise \%71,2'sinin ilk gebeliği olduğu, diğer adölesanların ise 2 . veya üzeri gebeliğinin olduğu rapor edilmiştir. Adölesan dönemde meydana gelen gebeliklerin tanısının konulmasında birçok nedene bağlı olarak zorluk görülebileceği, bu nedenle gebelik tanısı konulmakta geç kalındığı, bunun en önemli nedeni olarak da adölesandan alınan anamnezin yetersizliğinin gösterildiği, sonuç olarak da gebelikten şüphelenilmediği bildirilmiştir. Adölesan gebeler hastanelerde genellikle pediatri polikliniklerine ya da acil servislere başvuru yapmaktadır. Bu hastalarla ilk karşılaşan hekimlerin ayrıntılı anamnezi alması oldukça büyük önem taşımaktadır. Ancak bu yaşlardaki çocukların başta ebeveyn korkusu ve toplum baskısından dolayı doğru anamnez vermediği belirtilmiştir (1). Acil servise başvuran adölesanlardan gebe olduğu tespit edilenlerin sadece \%10'unun gebe olabileceğinin belirttiği, hatta olguların bir kısmının ise cinsel ilişkiyi inkâr ettiği, 
gebelik tanısı koyulamayan olguların \%68'inin ise hiçbir menstrüel ya da cinsel ilişki bilgisine rastlanmadığı bildirilmiştir (30).

Adölesan gebeliklerin saptandığı yılların dağııımına bakıldığında; olguların \%45,4'ünün 2019 yılında, \%36,5'inin 2018 yılında, \%18,1'inin 2020 yılında, ayrıca aylara göre dağılım incelendiğinde ise; en sık Temmuz ve Mayıs aylarında saptandığı görülmüş olup, yıllar ve aylar arasında istatistiksel bir anlamlılık saptanmamıştır.

Adölesan gebeliklerin erken dönemde tanınması, perinatal risklerin azaltılması ve komplikasyonların önlenmesi açısından oldukça büyük öneme sahiptir (31). Sunulan çalışmada adölesanların hastaneye ilk başvurdukları anda saptanan gebelik haftaları 3 ila 41 hafta arasında değişmekte olup, olguların yüksek oranda $(\% 54,6)$ üçüncü trimesterde olduğu belirlenmiştir. Ülkemizde adölesan gebeliklerle ilgili yapılan çalışmalarda gebeliğin toplam süresi belirtilmiş olmakla birlikte saptandığı andaki gebelik haftaları rapor edilmemiştir. Adölesan gebeliklerin saptanma haftası tıbbi, sosyal ve hukuki açıdan büyük önem taşımaktadır. Gebeliğin saptanma haftası, anne ve bebeğin sağlığı, gebenin sosyo-kültürel durumu ve yaşadığı ortamın özellikleri hakkında bilgi vermekte, ayrıca yaşanacak cezai süreci yakından ilgilendirmektedir. Adölesan gebeliklerin geç saptanması halinde anne ve bebeğin sağlığını olumsuz etkileyebilmekte, istemsiz bir gebelik söz konusu ise özellikle psikolojik açıdan gebeye zarar verebilmektedir.

Adölesan gebeliğin sonuçlarına ait spesifık risklerin mevcudiyeti ve gebelikten korunma düzeyinin yetersizliği bu konunun önemini daha fazla artırmaktadır. Adölesan gebeliklerde erken doğum riski, anemi, mineral eksiklikleri, düşük doğum ağırlığı, abortus, eklempsi / preeklempsi, yetersiz antenatal bakım, fetal anomaliler gibi anne ve bebeği tehdit eden sorunların daha sık yaşandığı, anne ölümlerinin yaklaşık beşte birinin adölesan gebeliklerde meydana geldiği belirtilmektedir $(1,2,22,32)$. Çalışmamızda gebe oldukları saptanan adölesanların 159 'unun gebelik sonucu bilgisine ulaşılmıştır. Bunların $\% 85,5$ 'inin hastanemizde canlı ve sağlıklı doğum yaptığı, $\% 8,2$ 'sinin ileri bir merkezlere sevk edildiği, \%6,3'ünün gebeliğinin abortusla sonuçlandığı tespit edilmiştir. Ülkemizde adölesanların incelendiği çalışmalara bakıldığında; Balcı ve ark.nın Amasya'da yaptığıçalışmada (29) \%8,5'inin, Yurtçu ve ark.nın Karabük'te yaptığı çalışmada (19) \%7,2'sinin, Akdemir ve ark.nın Sakarya'da yaptığı çalışmada (17) \%16'sının prematüre doğum yaptığı tespit edilmiştir. Sakarya çalışmasında (17) ayrıca olguların \%9'unda intrauterin ölüm, \%2,5'inde pospartum bebek ölümü, \%5'inde anomalili bebek doğumu, \%8'inde erken membran rüptürü, \%3'ünde preeklempsi, \%2'sinde eklempsi geliştiği, Melekoğlu ve ark.nın Adana'da yaptığı çalışmada (24) ise olguların \%56,3'ünde düşük doğum ağırlığı, \%31,3'üde preeklempsi, \%16,3'ünde konjenital anomali, \%20'sinde intrauterin gelişim geriliği, \%18,8'inde oligohidroamniyos, \%20'sinde fetal distres, \%1,3'ünde plasental anomali geliştiği, Kaya ve ark.nın Düzce'de yaptığı çalışmada (23) olguların \%24,3'ünde fetal distres, $\% 13,5$ 'inde malprezentasyon, $\% 10,8$ 'inde fetal makrozomi, $\% 13,5$ 'inde maternal anksiyete, $\% 2,7$ 'sinde maternal sistemik hastalık, \%12'sinde preeklempsi, \%9,6'sında intrauterin gelişim geriliği, \%2,4'ünde oligohidroamniyos geliştiği rapor edilmiştir.

Çalışmaya aldığımız adölesanların \%53,1'inin hastanemiz Kadın Hastalıkları ve Doğum kliniğinde, \%46,9'unun ise Acil Serviste gebe olduğu tespit edilmiş ve aynı birim hekimlerince adli birimlere bildirim yapıldığı görülmüştür. TCK'na göre "kamu adına soruşturma ve kovuşturmayı gerektiren bir suçun işlendiğini göreviyle bağlantılı olarak öğrenip de yetkili makamlara bildirimde bulunmayı ihmal eden veya bu hususta gecikme gösteren kamu görevlisi, altı aydan iki yıla kadar hapis cezası ile, Görevini yaptığı sırada bir suçun işlendiği yönünde bir belirti ile karşılaşmasına rağmen, durumu yetkili makamlara bildirmeyen veya bu hususta gecikme gösteren sağlık mesleği mensubu, bir yıla kadar hapis cezası ile cezalandırılacağı" belirtilmiştir (28). Adölesan dönemde gebelik saptanması sonrası adli mercilere yapılan bildirimler sağlık personelinin adli görevi niteliğindedir. Yasa koyucu, sağlık personelinin adli görevini yerine getirmemesi durumunda cezai müeyyide uygulanması gerektiğine karar vermiştir.

Sunulan çalışmada yabancı uyruklu olguların $\% 76,5$ 'inin 3. trimesterde olduğu $(p=0,000)$ ve $\% 10,3$ 'ünün 15 yaşın altında olduğu $(p=0,000), 15$ yaş altı olguların \%87,5'inin yabancı uyruklu olduğu $(p=0,000)$ ve bildirimin yapıldığı anda 3. trimesterde olduğu $(p<0,05)$ belirlenmiştir. Adölesanlarda doğurganlık sadece sağlık sorunları açısından değil aynı zamanda adölesanların eğitimlerini sürdürememesi, meslek sahibi olamaması, resmi nikâh yapılmaması veya gecikmesi ile erken yaşta doğurmanın daha geç doğurganlığa başlamaya göre genellikle daha çok doğuma neden olması ve ekonomik sorunların meydana gelmesi gibi sosyal sorunlara yol açması açısından oldukça büyük öneme sahiptir (2,33-35).

\section{Sınırlılıklar}

Çalışmanın yapıldığı İzmir Bakırçay Üniversitesi Çiğli Eğitim ve Araştırma Hastanesi'nde saptanan 18 yaş altı tüm gebelerin adli bildirim sonrasındaki süreçte hastanemize başvurmaması, böylece tüm gebeliklerin sonuçları (canlı ve sağlıklı doğum / ölü doğum / abortus) ve dolayısıyla anne-bebek sağlığı hakkında yeterli bilgiye ulaşılamaması, bildirim sonrası yapılan adli işlem bilgilerine ulaşılamaması, gebelerin medeni durum ve diğer sosyal durum bilgileriyle ilgiliyeterlibilgiyeulaşılamaması çalışmamızın sınırlılıklarını oluşturmaktadır.

\section{SONUÇ}

Adölesan gebelikler tıbbi, sosyal ve hukuki açıdan önemli bir halk sağlığı sorunudur. Hastanemizde adölesan dönem gebeliklerine rastlanması sonrası yapılan adli bildirimlerin yerinde olduğu görülmüştür. Ancak 
kullanılan bildirim formunda yer alan bilgilerin yeterliliği açısından yeniden gözden geçirilmesini önermekteyiz.

Adölesan gebelikleri önleyebilmek amacıyla gerek yüz yüze gerekse de kitle iletişim araçlarını kullanarak ve eğitim müfredatının zenginleştirilerek, eğitim kurumlarında cinsel sağlık derslerinin yaygınlaştırılması, sağlık kurumlarında ise adölesan gebeliklerin zararları konusunda hizmet veren polikliniklerin oluşturulması, böylece erken evlilik ve gebeliğin kişi ve toplum sağlığı üzerine olumsuz etkilerinin, adölesanların eğitiminin ve meslek sahibi olmasının önünde bir engel olduğunun ve ayrıca bir suç teşkil edebileceği gibi hukuki sonuçlarının topluma duyurulmasının faydalı olacağını düşünmekteyiz.

Teşekkür: Yazarlar, araştırmaya katkılarından dolayı Acil Tıp ve Jinekoloji hizmet ekibine teşekkür eder.

Finansal destek: Çalışmayı maddi olarak destekleyen kişi/kuruluş yoktur.

Çıkar Çatışması: Yazarlar arasında herhangi bir çıkar çatışması yoktur.

Etik onay: Çalışmamız Helsinki Deklarasyonu'na uygun olarak yürütülmüş olup bağımsız Etik Kurul Onayı bulunmaktadır (İzmir Bakırçay Üniversitesi Klinik Araştırmalar Etik Kurul Karar numarası: 102; Onay Tarihi: 12/10/2020).

\section{REFERENCES}

1. Keskin U, Kıncı MF. Adolescence period and pregnancies. Aydoğan Ü, Editor. Adolescent Health and Problems - I. Ankara: Turkis Clin 2018:33-8.

2. Şolt A, Yazıcı S. Adolescent pregnancies. HSP 2015;2:241-8

3. Kulhan M, Naykı ÜA, Naykı C, et al. Adolescent pregnancies in Erzincan province (Retrospective results of a single center). The Journal of Tepecik Education and Research Hospital 2016;26:215-20.

4. Anık Y, Ege E. Nursing approach in early marriages and adolescent pregnancies. Çelebioğlu A, Editor. Adolescent Health and Nursing Approaches. First edition. Ankara: Turkish Clin 2019:46-55.

5. World Health Organization (WHO) https://www.who.int/ access date 07.12.2020

6. Yılmaz E, Yılmaz Z, Yazıcı Işıtan Ö, et al. Obstetric and perinatal outcome of adolescent pregnant women who delivered in a training \& research hospital. J Gynecol Obst Neonatol 2015;12:213-6.

7. Nkhoma DE, Lin CP, Katengeza HL, et al. Girls' empowerment and adolescent pregnancy: A systematic review. Int J Environ Res Public Health 2020;17:1-14.

8. Finer LB, Zolna MR. Unintended pregnancy in the United States: incidence and disparities, 2006. Contraception 2011;84:478-85.

9. 9. Martin, JA. Births: Final Data for 2015. National vital statistics reports: from the centers for disease control and prevention, national center for health statistics. National Vital Statistics System 2017;66:1.
10. Mclntyre P. Pregnant adolescents delivering on global promises of hope. Geneva, WHO Library Cataloguing-inPublication Data 2006;4-7.

11. Türkiye Nüfus ve Sağlık Araştırmaları (TNSA). Hacettepe Üniversitesi Nüfus Etütleri Enstitüsü Ankara, Türkiye, 2018. http://www.hips.hacettepe.edu.tr/tnsa2018/rapor/ TNSA2018_ana_Rapor.pdf access Date 07.12.2020

12. Türkiye İstatistik Kurumu (TÜiK) https://www.tuik.gov.tr/ access date 07.12.2020

13. Başer M. Adölesan cinselliği ve gebelik. Cumhuriyet Üniversitesi Hemşirelik Yüksekokulu Dergisi 2000;4:50-4.

14. Güzel Al, Tokmak A, Ustun YE. Adölesan Gebelikler. Jinekoloji-Obstetrik ve Neonatoloji Tıp Dergisi 2016;13.

15. Keskin Kurt R, Karateke A, Aras Z, et al. Maternal and fetal outcomes of adolescent pregnancies in hatay province. ODU J Med 2014:e68-e71.

16. Ayyıldız T, Topan A, Öztürk Ö, et al. Evaluation of adolescent pregnancies in terms of obstetric outcomes for the mother and the newborn. DEUHFED 2015;8:61-6.

17. Akdemir N, Bilir F, Cevrioğlu AS, et al. Investigation of obstetric outcomes of adolescent pregnancies in Sakarya region. Sakaryamj 2014;4:18-21.

18. Illeri A, İleri $H$, Ata Can. Comparison of maternal and fetal outcomes in adolescent pregnancies. Bozok Med $\mathrm{J}$ 2020;10:24-9.

19. Yurtçu E, Mutlu S, Çitil A. Comparison of perinatal outcomes between adolescent and adult pregnancies: A retrospective study. Osmangazi J Med 2020 2020;42:603-8.

20. Yıldızhan R, Kolusarı A, Edirne T. Analysis of adolescent pregnancies in van region. Van Med J 2009;16:124-7.

21. Songur Dağlı S, Karbancıoğlu Cantürk F. Adolescent pregnancies. Bozok Med J 2019;9:9-13.

22. İnalöz EY, İngeç $M$, Topdağı Yılmaz EP. Evaluation of the effects of adolescent pregnancies on maternal and perinatal outcomes in our region. Mustafa Kemal Üniv Tıp Derg 2017;8:6-14.

23. Ellibeş Kaya A, Başbuğ A, Sönmez Cl. et al. Late adolescent pregnancies, maternal and fetal outcomes. Fam Pract Palliat Care 2017;2:22-7.

24. Melekoğlu R, Evrüke C, Kafadar T, et al. Perinatal outcomes of adolescent pregnancy. J Turk Soc Obstet Gynecol 2013;10:213-9.

25. Zhang $T$, Wang $H$, Wang $X$, et al. The adverse maternal and perinatal outcomes of adolescent pregnancy: A cross sectional study in Hebei. China Pregnancy and Childbirth 2020;20:339.

26. Türk Medeni Kanunu (TMK) https://www.mevzuat.gov.tr/ MevzuatMetin/1.5.4721.pdf access date: 07.12.2020

27. Akıntürk T, Karaman DA. Marriage. Civil Law. Beta edition, İstanbul, 2012;236-44.

28. Türk Ceza Kanunu (TCK) https://www.mevzuat.gov.tr/ MevzuatMetin/1.5.5237.pdf access date: 07.12.2020

29. Balcı RE, İncedal Sonkaya Z, Göçer Ş. Adolescent and nonadolescent pregnant women. East J Med 2020;25:19-25.

30. Causey AL, Seago K, Wahl NG, et al. Pregnant adolescents in the emergency department: Diagnosed and not diagnosed. The American Journal of Emerg Med 1997;15:125-9. 
31. Lindahl V, Pearson JL, Colpe L. Prevalence of suicidality during pregnancy and the postpartum. Arch Women's Mental Health 2005;8:77-87.

32. Kütük S. Pregnancy in adolescents, risks and problems. TAHUD 2012;16(Suppl):31-4.

33. Öner S, Yapıcı G. Overview of adolescent pregnancies. Turk J Public Health 2010;8(1):30-9.
34. World Health Organization. Early marriages, adolescent and young pregnancies: Report by the Secretariat. WHO, SixtyFifth World Health Assembly. Geneva, 2012.

35. Marvin-Dowle K, Soltani H. A comparison of neonatal outcomes between adolescent and adult mothers in developed countries: A systematic review and metaanalysis. Eur J Obst Gynecol Reproductive Biol X 6 2020;1 13100109. 